\title{
SIGNIFICANCE OF BIOGENIC AMINES IN COLD-SMOKED FISH AND THEIR RELATION TO MICROBIOLOGICAL CHARACTERISTICS OF PRODUCTS AVAILABLE IN PORTUGUESE RETAIL MARKETS
}

\author{
Manuela V. da Silva, Paul Gibbs
}

\begin{abstract}
Studies on microbial characterization of cold-smoked salmon and salmon trout during cold storage were performed on samples available in the Portuguese market. Samples were also classified microbiologically according to guidelines for ready-to-eat (RTE) products. Further investigations on sample variability and microbial abilities to produce tyramine and histamine were also performed. The coefficient of variation for viable counts of different groups of microorganisms of samples collected at retail market point was high in the first $\mathbf{2}$ wk of storage, mainly in the Enterobacteriaceae group and aerobic plate count (APC), suggesting that microbiological characteristics of samples were different in numbers, even within the same batch from the same producer. This variation seemed to be decreased when storage and temperature were controlled under lab conditions. The numbers of Enterobacteriaceae were influenced by storage temperature, as indicated by low microbial numbers in samples from controlled refrigeration. Lactic acid bacteria (LAB) and Enterobacteriaceae were predominant in commercial products, a significant percentage of which were tyramine and less histamine producers. These results might be influenced by (1) the technological processes in the early stages of production, (2) contamination during the smoking process, and (3) conditions and temperature fluctuations during cold storage at retail market point of sale.
\end{abstract}

Seafood-borne diseases are a major concern of consumers, producers, and authorities and may be produced by a variety of agents, including aquatic toxins, biogenic amines, bacteria, viruses and parasites (Gram \& Huss, 2000; Iwamoto et al., 2011). The growing consumer interest in food quality and nutritional issues, have contributed to the increase of consumption of fish and fish products. Risk perception studies showed that individuals may underestimate significant risks while overestimating others, lowering their perceived risk but not the actual risk. Despite the potentially high biological activity of many biogenic amines and their occurrence in several foods, these substances may be significantly underestimated
(Burger et al., 1993; Burger, 1998; Kramer and Scott, 2004; Fatimah et al., 2011). High levels of biogenic amines may be formed before foods appear spoiled or organoleptically unacceptable. Biogenic amines are formed in foods as a result of microbial action during storage, usually formed during decomposition or spoilage processes involving formation of free amino acids through proteolysis, together with bacterial production and action of amino acids decarboxylases (Ten Brink et al., 1990; Shalaby, 1996; Kuley et al., 2011). Biogenic amines are toxic substances and are attributed with producing diseases in humans and animals, especially with respect to histamine and tyramine (Til et al., 1997; European Food Safety Authority 
[EFSA], 2011). In addition, some amines may be nitrosated or act as precursors for other compounds capable of forming nitrosamines, which are carcinogenic to various animals and a potential hazard for humans (Shalaby, 1996).

Cold-smoked fish products have received attention in terms of chemical and microbiological safety, from studies on detection and quantification of pathogenic microorganisms such as Listeria monocytogenes using technological strategies to ensure quality and safety (Vaz-Velho et al., 2005, 2006; Calo-Mata et al., 2008; Vermeulen et al., 2011; Todorov et al., 2012) to investigations on spoilage characterization examining the presence of biogenic amines (Jørgensen et al., 2000a; Joffraud et al., 2001; Chytiri et al., 2004; Dalgaard et al., 2008; Fadhlaoui-Zid et al., 2012). Identification of the spoilage microflora and biogenic amine production of single and cocultures growing in cold-smoked salmon was also studied by Jorgensen et al. (2000b), and these have been used as chemical indicators of seafood quality (Jørgensen et al., 2000a; Ozogul and Ozogul, 2006; Fadhlaoui-Zid et al., 2012).

Strains of Enterobacteriaceae and lactic acid bacteria (LAB) are the predominant microflora associated with cold-smoked fish and identified as active amine producers (Leroi et al., 2000; Jorgensen et al., 2000a; Silva et al., 2002). Jørgensen et al. (2000a) found Photobacterium phosphoreum to be primarily responsible for the production of biogenic amines in vacuumpacked cold-smoked salmon, where agmatine (160-220 mg/kg), cadaverine (260-470 mg $/ \mathrm{kg})$, histamine (100-220 $\mathrm{mg} / \mathrm{kg})$ and tyramine $\left(50-130 \mathrm{mg} / \mathrm{kg}\right.$ ) were formed at $5^{\circ} \mathrm{C}$.

In the Portuguese commercial market the majority of the vacuum-packed cold-smoked salmon originate from other European countries. The differences in origins of raw material and European producers make shelf lives quite different. In Portugal the production of cold-smoked fish is almost associated with cold-smoked salmon (Salmo salar) and salmontrout (Oncorhynchus mykiss), with the latter raw material being produced in the north of
Portugal. However, little information is available on microbial characterization of cold-smoked fish products available in the Portuguese market, their microbial variability, and their influence on biogenic amines production. This information is important due to their potential impacts on human health and food quality. The main objective of this study was to determine microbial characterization and quality of cold-smoked fish products available in the Portuguese market, and their potential to produce biogenic amines. Characterization of the microbiological profile during storage and at the end of shelf life, and studies on batch variability, levels of microbial hygiene indicators, and the related microbial quality were performed based upon European guidelines for commercial vacuum-packed cold-smoked salmon available on the market. The potential of bacterial isolates to produce biogenic amines was also examined.

\section{MATERIALS AND METHODS}

\section{Smoked Fish Samples}

Fish samples were obtained from Portuguese retail market (experiment I and experiment II) and for experiment III, directly from Portuguese producers at the end of production day. Cold-smoked salmon (Salmo salar) and cold-smoked salmon-trout (Oncorhinchus mykssis) were stored under refrigerated conditions $\left(5^{\circ} \mathrm{C}\right)$. Samples analyzed were sliced fish fillets stored under vacuum packing. In each experiment, all samples were microbiologically analyzed every week, until the expiry date (experiment I) and during $4 \mathrm{wk}$ of storage (experiments II and III).

\section{Microbiological Analysis}

From each pack, $30 \mathrm{~g}$ of cold-smoked fish was taken aseptically $(10 \mathrm{~g}+10 \mathrm{~g}+10 \mathrm{~g}$, from 3 different parts of the sample) and homogenized for $90 \mathrm{~s}$ in a stomacher (Seward 400). Ten grams of the mixture was aseptically taken and decimally diluted in sterile Maximum Recovery Diluent (CM 733; Oxoid) and homogenized for 
20 s. Aerobic plate counts were performed on spread plates of Long and Hammer's medium (LH) (Van Spreekens, 1974) with additional 1\% $\mathrm{w} / \mathrm{v} \mathrm{NaCl}$, incubated at $15^{\circ} \mathrm{C}$ for $5-7 \mathrm{~d}$. Counts of lactic acid bacteria (LAB) were obtained from pour plates of NAP medium, $\mathrm{pH} 6.7$ (Davidson \& Cronin, 1973), incubated anaerobically (Anaerocult A, Merck) at $21^{\circ} \mathrm{C}$ for $5 \mathrm{~d}$. Enterobacteriaceae counts were obtained from pour plates of $5 \mathrm{ml}$ tryptone soya agar (TSA), and after 2-h resuscitation of damaged cells at $20-25^{\circ} \mathrm{C}$ plates were overlaid with $12-15 \mathrm{ml}$ of violet red bile glucose agar (VRBGA). Typical Enterobacteriaceae colonies were counted after $2 \mathrm{~d}$ of incubation at $30^{\circ} \mathrm{C}$. To assess the selectivity of the different media, representative colonies were selected from plates and the following tests were performed: cell morphology, gram stain, and catalase and oxidase tests.

\section{Bacterial Isolates}

Representative colonies that grew on Long and Hammer's plates were selected and maintained on nutrient agar slants and stored at $5^{\circ} \mathrm{C}$. Identification of the $\mathrm{LAB}$ group was based on the gram reaction, absence of catalase and cytochrome oxidase, and fermentative catabolism of glucose. For selected strains, API 20E (BioMérieux) and API 50CHL (BioMérieux) were used for identification of gram-negative strains and $L A B$, respectively.

\section{Determination of Decarboxylase Capability}

Thirty-two gram-negative and 22 strains that were included in the LAB group were selected to investigate the decarboxylating ability. The medium used to detect decarboxylating strains was prepared as described by Niven et al. (1981) and Silva et al. (2002). Strains were prepared for testing by subculturing in nutrient broth (NB) (Lab M) supplemented with $0.4 \%(\mathrm{w} / \mathrm{v})$ each of the amino acids histidine and tyrosine, and incubated at $25^{\circ} \mathrm{C}$ for $48 \mathrm{~h}$. A portion of each culture was spread on the decarboxylation agars, which were then incubated anaerobically (Anaerocult A, Merck) at 25 or $5^{\circ} \mathrm{C}$ for $48 \mathrm{~h}$ and $10 \mathrm{~d}$, respectively. A purple halo was interpreted as positive for amine production. All strains were tested twice on separate occasions.

\section{Examination of Proteolytic and Lipolytic Activity}

Milk agar (10\%) (Sigma-Aldrich) and tributyrin agar (Merck) were used to select bacteria that have proteolytic and lipolytic activity, respectively. The positive reaction was interpreted by a presence of a translucent halo surrounding the colonies.

\section{RESULTS}

\section{Products and Storage Characteristics}

The cold-smoked fish samples were in general exposed in the market at $5 \pm 1{ }^{\circ} \mathrm{C}$ in a commercial refrigerator open to consumers. The shelf life of the samples varied from 2 to $6 \mathrm{wk}$ and, with the exception of one sample that was from Scotland, all others were from Norway (Table 1). Samples that originated directly from Portuguese smokehouses were stored at $4 \pm 1^{\circ} \mathrm{C}$. It was observed that one Portuguese smokehouse introduced a previous step of rapid freezing at $-20^{\circ} \mathrm{C}$ after production, to improve the slicing process, and before chill commercialization. None of the samples showed any visual changes at the moment of collection.

\section{Microbial Numbers and Characteristics}

The microbiological characteristics of coldsmoked salmon samples from different producers and countries available on the Portuguese market are shown in Table 1. In general, microbial numbers increased during storage, with the exception of numbers of Enterobacteriaceae, which showed low initial numbers, with the exception of producer B (sample in the first week of storage) and producer $M$ (sample at $2 \mathrm{wk}$ of storage). At the end of shelf-life date 


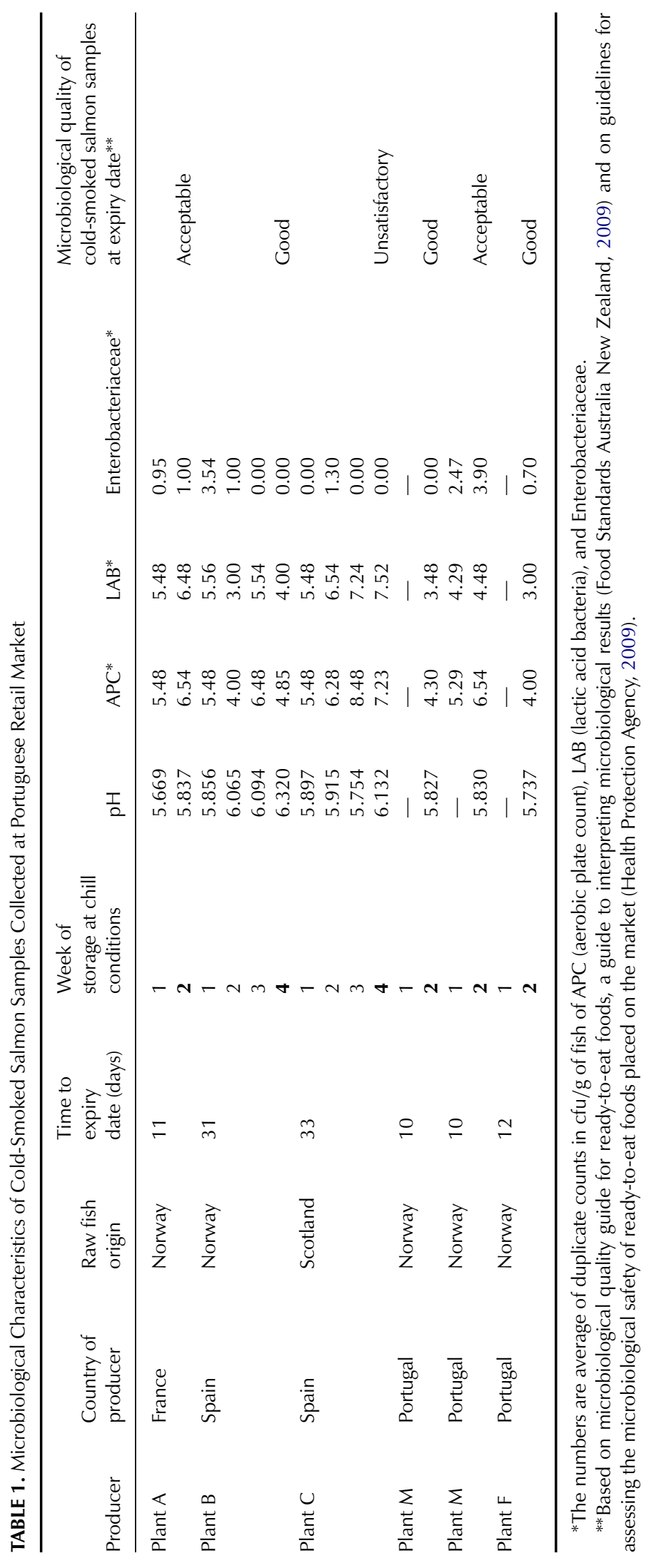


and based on "Quality Guide for Ready-to-Eat Foods, A Guide to Interpreting Microbiological Results" (references for APC: good, $<10^{6}$; acceptable, $<10^{7}$ and $\geq 10^{6}$; unsatisfactory, $\geq 10^{7}$; references for Enterobacteriaceae group: good, $<10^{2}$; acceptable, $\geq 10^{2}$ and $<10^{4}$; unsatisfactory, $\geq 10^{4}$ ) (Food Standards Australia New Zealand, 2009), the results of microbial quality revealed one sample as "unsatisfactory," two samples "acceptable," and three samples classified as "good" (Table 1). A numerical increase of $\mathrm{pH}$ occurred in all samples during storage. In order to understand the variability of the microbial quality of cold-smoked fish products available on the Portuguese market (within the same producer and batch and between different producers), characterization of samples was performed. Data are shown in Table 2. Generically for the first 2 wk of storage, the coefficient of variation (CoV) of samples is high, mainly for the Enterobacteriaceae group and less for other groups of microorganisms (Table 2). The presented findings are an average of the group of samples in each week of sampling, for determination of the $\mathrm{CoV}$, and consequently did not differentiate microbiological quality of samples within the same group. Although not shown in Table 2, some samples were beyond the limit of acceptance criteria for microbiological quality, even before the expiry date, based on the "Guidelines" (Food Standards Australia New Zealand, 2009; Health Protection Agency [HPA], 2009): Plant F, wk 2 (APC: 6.52 $\pm 1.31 \mathrm{CFU} / \mathrm{g}$; Enterobacteriaceae: $2.11 \pm$ 2.07 CFU/g), Plant F, wk 2 (APC: 7.48 $\pm 0.00 \mathrm{CFU} / \mathrm{g}$; Enterobacteriaceae: 5.30 $\pm 0.37 \mathrm{CFU} / \mathrm{g}$ ), and Plant Sp, wk 1 (Enterobacteriaceae: $4.68 \pm 0.64 \mathrm{CFU} / \mathrm{g}$ ).

The analysis of cold-smoked salmon collected directly at the end of production in Portuguese smokeries and cold-stored for $4 \mathrm{wk}$ under lab-controlled time and temperature storage conditions is presented in Table 3. The CoV of these particular samples was lower compared to data in Table 2. In addition, the numbers of Enterobacteriaceae were considerably reduced in products from Portuguese plants $S$ and $M$, compared to the other plants. Even though the CoV were in some cases higher than $20 \%$, in general these values were essentially related to samples at the same storage period (first $2 \mathrm{wk}$ ).

\section{Biogenic Amines Production by Bacteria}

Bacterial strains were selected based on predominant colonies on agar plates from different storage times and from different producers. Tables 4 and 5 identified the amines producer bacteria, revealing positive reactions to tyramine and histamine based on appearance of a purple color around the colonies. Further identification to the genus and/or species level and its proteolytic and lipolytic activities are also shown. The results indicated a low percent of bacterial strains that displayed proteolytic activity (less than 5\% and less than 13\% for bacteria that were gram-positive and gramnegative, respectively). Higher percentages for lipolytic activity were observed $(31 \%$ and $19 \%$ for bacteria that were gram-positive and gramnegative, respectively).

Overall, data indicated that the number of tyramine producers was higher than the number of histamine producers. At $25^{\circ} \mathrm{C}$, gram-negative strains showed positive reactions for histamine and tyramine production, $40.6 \%(13 / 32)$ and $68.8 \%(22 / 32)$, respectively. At lower temperatures $\left(5^{\circ} \mathrm{C}\right)$, these values decreased to $31.3 \%(10 / 32)$ and $37.5 \%$ $(12 / 32)$, respectively. Bacteria responsible for this were identified as Serratia liquefaciens/S. marcescens and Enterobacter spp. For grampositive strains, the findings at $25^{\circ} \mathrm{C}$ displayed percentages of $21 \%$ (4/19) and $47.4 \%$ (9/19) for histamine and tyramine production, respectively. At $5^{\circ} \mathrm{C}$, only tyramine-producing strains were detected $(16.7 \% ; 3 / 18)$.

\section{DISCUSSION}

Commercial cold-smoked salmon and salmon-trout are the major smoked fish products available on the Portuguese market. In the last few years several studies have focused on characterization of microbiological patterns 


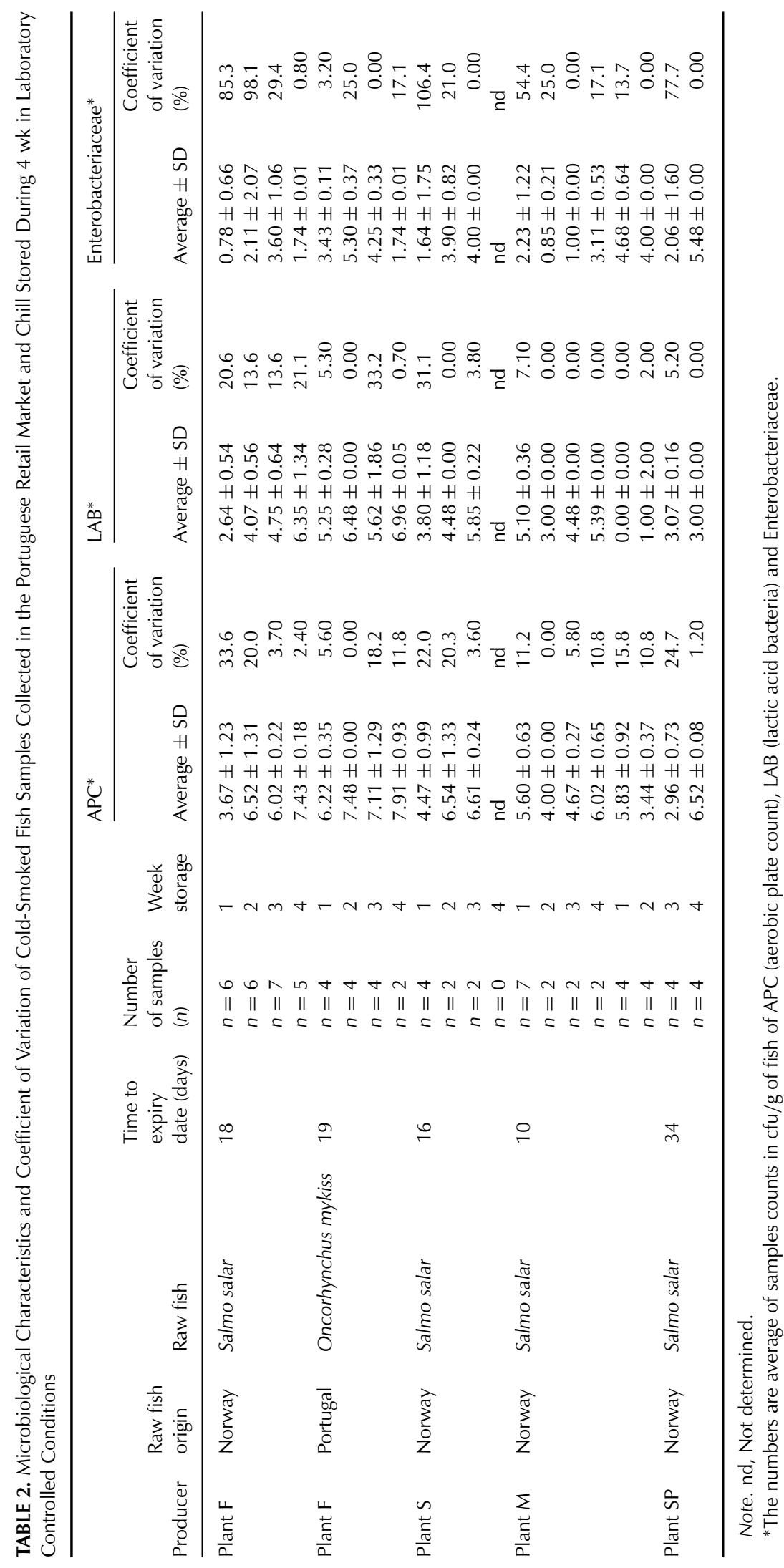




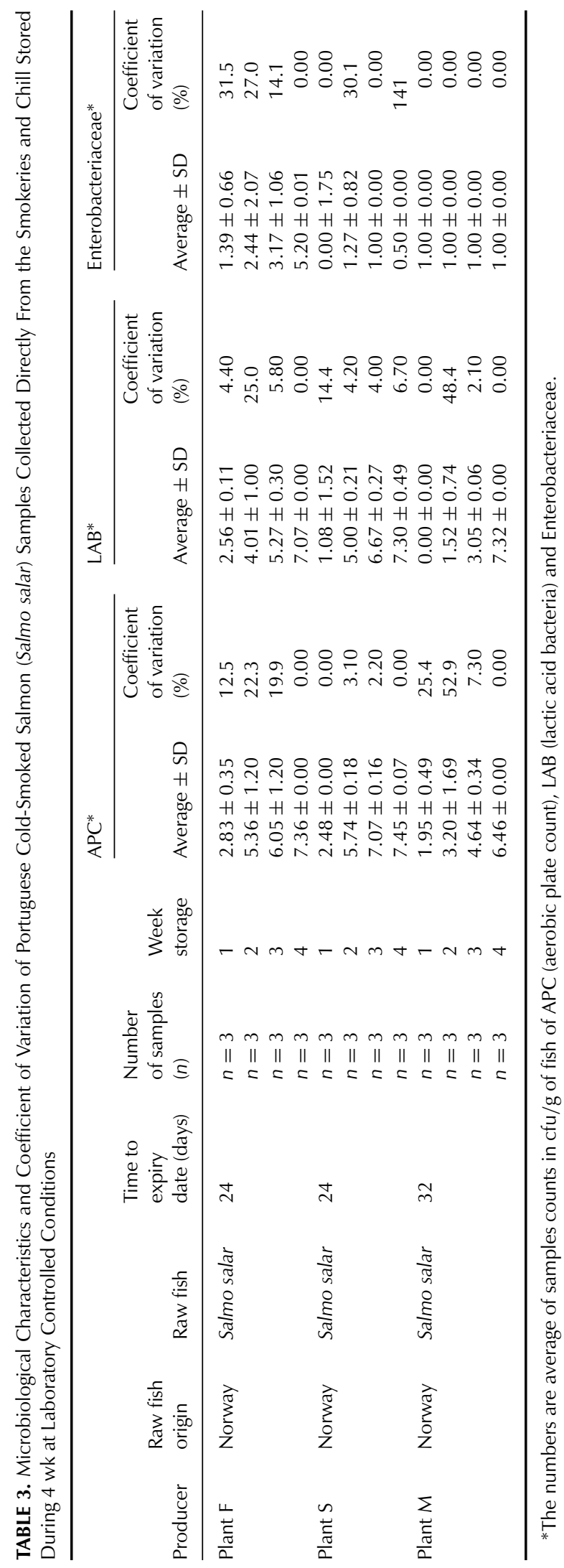




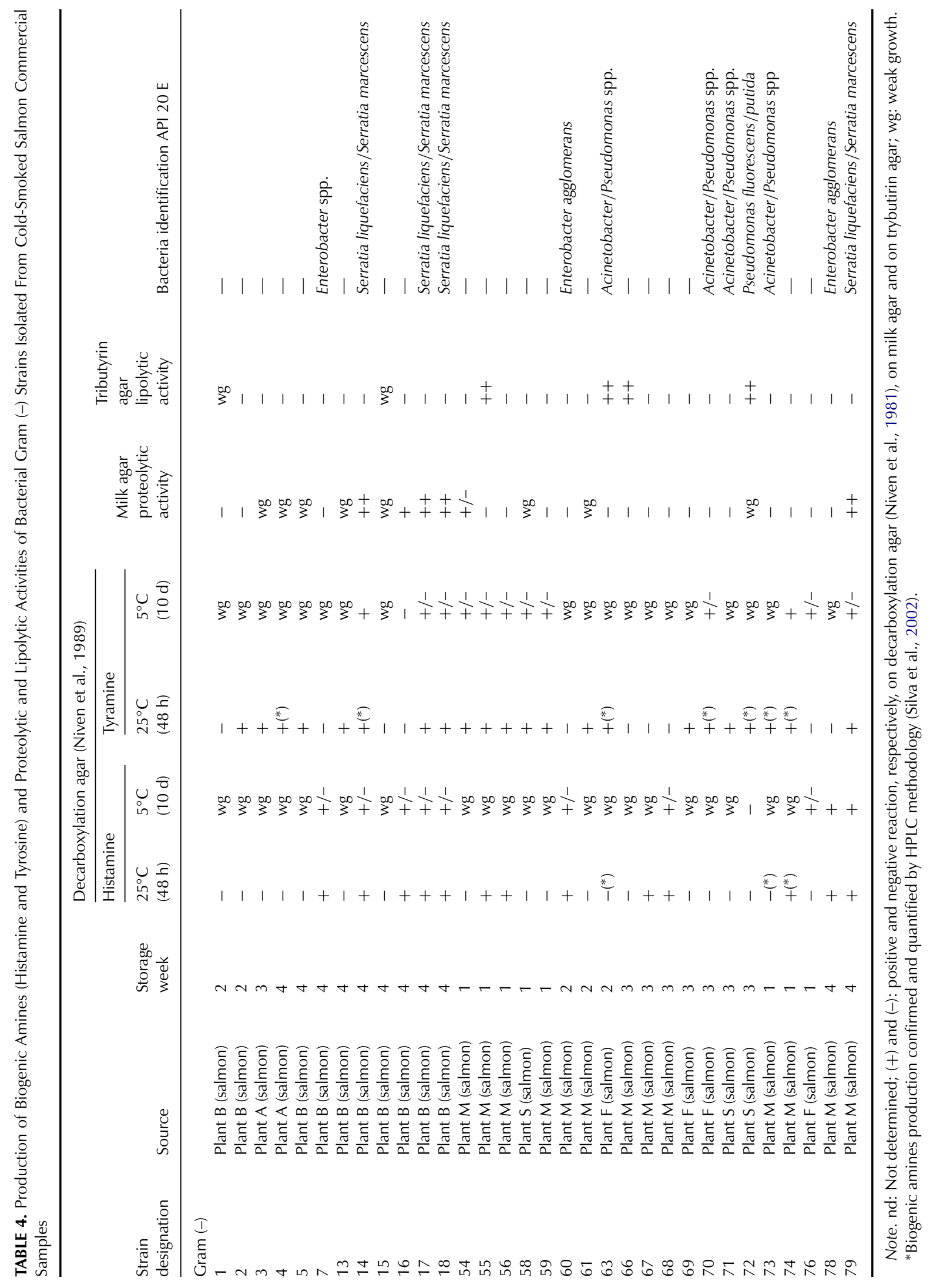




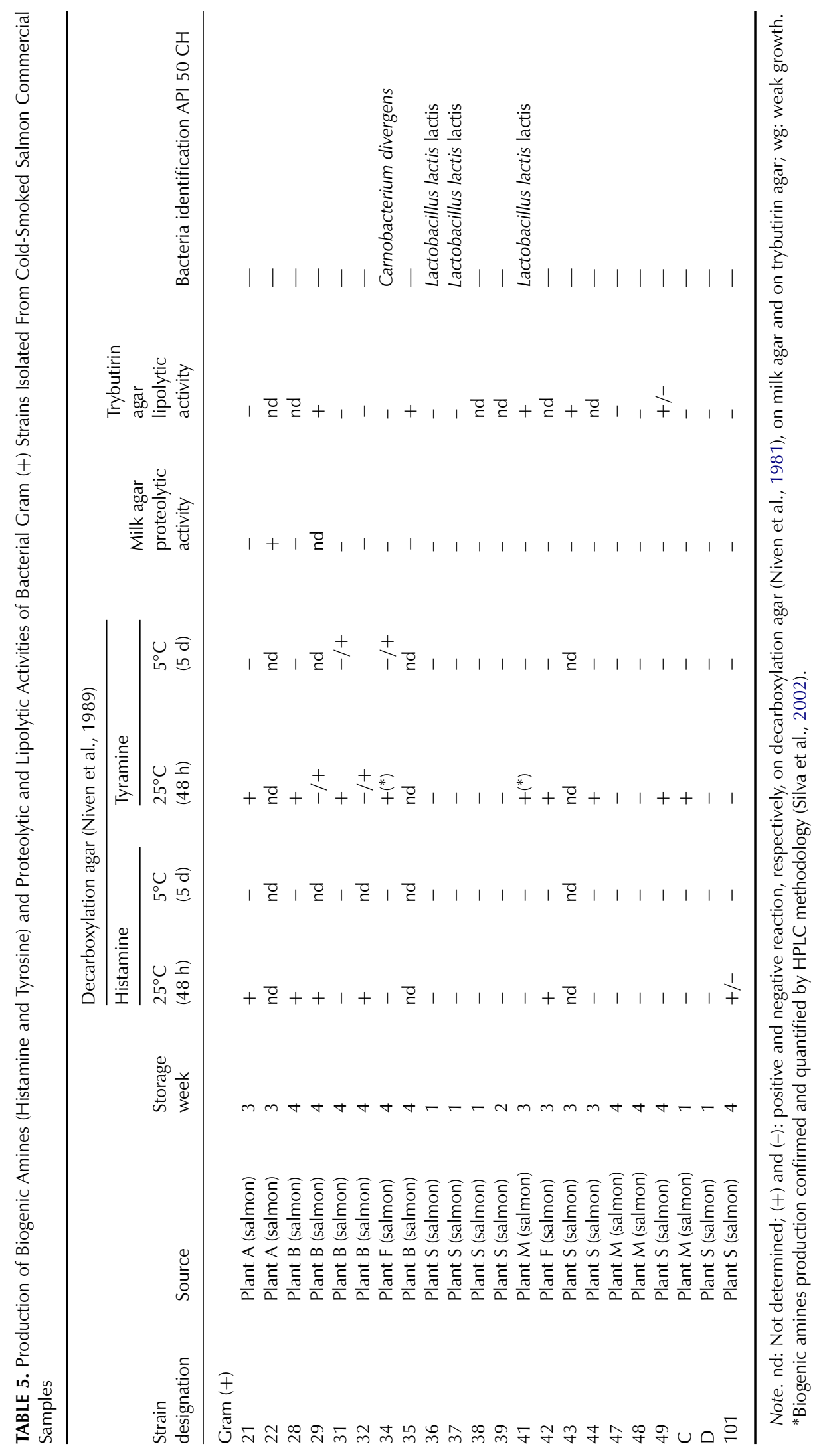


and spoilage processes, and on control of pathogenic bacteria, such as L. monocytogenes, in cold-smoked fish. EFSA (2011) indicated that the "safety of consumers" was dependent not only on the presence of this pathogen but also on levels of the biogenic amines tyramine and histamine produced by decarboxylation of amino acid precursors. Thus, evaluation of the presence of these biogenic amines in coldsmoked fish products and identification of the biogenic amino producer's bacteria are of concern for public health, consumers, and producers. In fact, it is known that microbial activity is responsible for spoilage and quality deterioration of these products, and as the presence of biogenic amines is dependent on the composition of the microflora, it is important to ascertain the sources of this microflora, including poor hygiene practices, preservation and technological procedures, and storage conditions (Food and Drug Administration [FDA], 2004; EFSA, 2011; Fadhlaoui-Zid et al., 2012). In this study, the CoV of the samples indicated that the microbial quality was not homogeneous within a batch, and at the expiry date samples showed different levels of contamination. Several technological factors, such as salting and smoking procedures, and packaging conditions, in combination with storage temperatures and hygiene procedures, exert a direct influence on microbial characteristics and microbial growth (Leroi et al., 2000; Cid et al., 2008; EFSA, 2011; Zhai et al., 2012). Data indicated that the storage and temperature conditions influenced microbial growth, a fact easily observed when comparing samples stored in controlled temperature conditions in the lab that present low CoV compared to the ones stored in retail market conditions. In this study, $\mathrm{LAB}$ and Enterobacteriaceae were the predominant groups present in commercial vacuumpacked cold-smoked fish, and this is in agreement with other previous studies (Leisner et al., 1994; Hansen, 1995; Jorgensen et al., 2000b). However, some differences in the behavior of $\mathrm{LAB}$ and Enterobacteriaceae in products were observed among the different producers. The results demonstrated that the CoV of samples decreased with storage time (Tables 2 and 3).
Further, the CoV of samples was higher for Enterobacteriaceae and aerobic plate count, especially in the first week of storage, with values also declining correlated to further storage time. Data suggest that the determinant factors influencing microbial characteristics, such as raw material quality and technological process (salting and cold-smoking), in combination with good manufacturing practices, exert major influences on the quality attributes of the final product. However, storage temperature fluctuations, which may occur at distribution and retail points, also exert a considerable influence. These results are in agreement with Dondero et al. (2004), who demonstrated that the quality and shelf life of cold-smoked salmon was a function of storage temperature control. The findings also showed that a significant number of bacteria present on commercial Portuguese cold-smoked salmon produce tyramine and histamine, dependent on the producer and week of storage. The presence of high levels of LAB and Enterobacteriaceae in products may be associated with the presence of biogenic amine-producing bacteria, since some species of these groups are indicated as biogenic amines producers (Jorgensen et al., 2000b; Cid et al., 2008; Curiel et al., 2011; Bunka et al., 2013). Most of these Enterobacteriaceae belong to the genera Serratia and Enterobacter, the most frequently isolated from cold-smoked salmon (Hansen and Huss, 1995; Jorgensen et al., 2000a; Silva et al., 2002). The higher LAB counts generally present in these products, in conjunction with Enterobacteriaceae (or other spoilage microorganisms e.g. Photobacterium phosphoreum), seem to be a general occurrence. Hansen (1995) indicated that producers need to pay special attention to the inclusion of a contaminating flora via fair hygiene conditions and poor manufacturing practices that might contribute to heavy spoilage and biogenic amines production. In addition, Lactobacillus curvatus was identified as a specific spoilage organism in cold-smoked salmon, probably with a spoilage domain different from $P$. phosphoreum (Jorgensen et al., 2000a; Dalgaard et al., 2008). In addition to tyramine and histamine 
production, some strains displayed proteolytic activity that may contribute to the production of biogenic amines, due to the availability of proteins and amino acids in fish muscle. In our study the results were positive for the presence of the two bacterial strains, Serratia liquefaciens/Serratia marcescens. Data demonstrated that some samples before the expiry date were microbiologically unsatisfactory, presenting high microbial numbers for aerobic plate counts or presenting high numbers of the Enterobacteriaceae group, indicating poor microbiological quality. Further, a high percentage of tyramine-producing bacteria and some histamine producers suggested that the microbial characteristics of samples were not homogeneous within a producer (and batch), which implies that improvements to standardize methods and procedures in cold-smoked fish production need be considered, as well as procedures monitoring the hygiene and storage conditions at distribution and retail level.

\section{FUNDING}

The authors acknowledge PRAXIS XXI for financial support.

\section{REFERENCES}

Buñka, F., Budinský, P., Zimáková, B., Merhaut, M., Flasarová, R., Pachlová, V., Kubáñ, V., and Buñková, L. 2013. Biogenic amines occurrence in fish meat sampled from restaurants in region of Czech Republic. Food Control 31: 49-52.

Burger, J., Staine, K., and Gochfeld, M. 1993. Fishing in contaminated waters: Knowledge and risk perception of hazards by fishermen in New York City. J. Toxicol. Environ. Health A 39: 95-105.

Burger, J. 1998. Fishing in contaminated waters: Knowledge and risk perception of hazards by fishermen in New York City. J. Toxicol. Environ. Health A 53: 181-192.

Calo-Mata, P., Arlindo, S., Boehme, K., Miguel, T., Pascola, A., and Barros-Velasquez J. 2008. Current applications and future trends of lactic acid bactéria and their bacteriocins for the biopreservation of aquatic food products. Food Bioprocess. Technol. 1: 43-63.

Chytiri, S., Paleologos, E., Savvaidis, I., and Kontominas, M. G. 2004. Relation of biogenic amines with microbial and sensory changes of whole and filleted freshwater rainbow trout (Oncorhynchus mykiss) stored on ice. J. Food Protect. 67: 960-965.

Cid, B. S., Miguelez-Arrizado, J., Becker, B., Holzapfel, W. H., and Vidal-Carou, M. C. 2008. Amino acid decarboxylation by Lactobacillus curvatus CTC273 affected by the $\mathrm{pH}$ and glucose availability. Food Microbiol. 25: 269-277.

Curiel, J. A., Ruiz-Capillas, C., de las Rivas, B., Carrascosa, A. V., Jiménez-Colmenero, F., and Muñoz, R. 2011. Production of biogenic amines by lactic acid bacteria and enterobacteria isolated from fresh pork sausages packaged in different atmospheres and kept under refrigeration. Meat Sci. 88: 368-373.

Dalgaard, P., Emborg, J., Kjolby, A., Sorensen, N., and Ballin, N. 2008. Histamine and biogenic amines-Formation and importance in seafood. In Improving seafood products for the consumer, ed. T. Borrensen, 292-324. Cambridge, UK: Woodhead Publishing Ltd.

Davidson, C. M., and Cronin, F. 1973. Medium for the selective enumeration of lactic acid bacteria from foods. Appl. Microbiol. 26: 439-440.

Dondero, M., Cisternas, F., Carvajal, L., and Simpson, R. 2004. Changes in quality of vacum-packed cold-smoked salmon (Salmo salar) as a function of storage temperature. Food Chem. 87: 543-550.

European Food Safety Authority. 2011. European Food Safety Authority (EFSA) panel of biological hazards. Scientific opinion on risk based control on biogenic amines formation in fermented food. EFSA J. 9: 2393. www.efsa.europa.eu/efsajournal

Fadhlaoui-Zid, K. Curiel, J. A., Landeta, G., Fattouch, S., Reverón, I., de las Rivas, B., Sadok, S., and Muñoz, R. 2012. Biogenic amine production by bacteria isolated from ice-preserved sardine and mackerel. Food Control 25: 89-95. 
Fatimah, U. Z. A. U., Boo, H. C., Sambasivan, M., and Salleh, R. 2011. Foodservice hygiene factors - the consumer perspective. Int. J. Hosp. Manage. 30: 38-45.

Food and Drug Administration. 2004. Report on the occurrence of foodborne illness risk factors in selected institutional foodservice, restaurant and retail-food store facility types. Washington, DC: U.S. Public Health Service, FDA, Department of Health and Human Services.

Food Standards Australia New Zealand. 2009. Guidelines for the microbiological examination of ready-to-eat foods. http:// www.foodauthority.nsw.gov.au/_Documents/ science/microbiological_quality_guide_for_ RTE food.pdf

Gram, L., and Huss, H. H. 2000. Fresh and processed fish and shellfish. In The microbiological safety and quality of foods, ed. B. M. Lund. T. C. Baird-Parker, and G. W. Could, 472-506. Gaithersburg, MD: Aspen.

Hansen, T. 1995. Quality of chilled, vacuum packed cold-smoked salmon. PhD thesis, Danish Institute of Fisheries Research, Department of Seafood Research, Lyngby, Denmark.

Hansen, L. T., and Huss, H. H 1995. Comparison of the microflora isolated from spoiled cold-smoked salmon from three smokehouses. Food Res. Int. 31: 703-711.

Health Protection Agency. 2009. Health Protection Agency-Corporate plan 2009. Guidelines_for_assessing the microbiological_safety_of_ready-to-eat_ foods_on_the_market.pdf. https://www. gov. uk/government/uploads/system/uploads/ attachment_data/file/363146

Huss, H. H. 1994. Assurance of sea food quality. FAO Fisheries Technical Paper 334. http://www.fao.org/docrep/003/t1768e/ t1768e00.htm

Iwamoto, M., Ayers, T., Mahon, B. E., and Swerdlow, D. L. 2011. Epidemiology of seafood-associated infections in the United States. Clin. Microbiol. Rev. 23: 399-411.

Joffraud, J. J., Leroi, F., Roy, C., and Berdagué, J. L. 2001. Characterization of volatile compounds produced by bacteria isolated from the spoilage flora of cold-smoked salmon. Int. J Food Microbiol. 66: 175-184.

Jorgensen, L. V., Dalgaard, P., and Huss, H. H. 2000b. Multiple compound quality index for cold-smoked salmon (Salmo salar) developed by multivariate regression of biogenic amines and pH. J. Agric. Food Chem. 48: 2448-2453.

Jorgensen, L. V., Huss, H. H. \& Dalgaard, P. 2000a. The effect of biogenic amine production by single bacterial cultures and metabiosis in cold-smoked salmon. J. Appl. Microbiol. 89: 920-934.

Kramer, J., and Scott, W. G. 2004. Food safety knowledge and practices in ready-toeat food establishment. Int. J. Environ. Health Res. 14: 343-350.

Kuley, E., Ozogul, F., Ozogul, Y., and Akyol, I. 2011. The function of lactic acid bacteria and brine solutions on biogenic amines formation by foodborne pathogens in trout fillets. Food Chem. 129: 1211-1216.

Leroi, F., Joffraud, J. J. and Chevalier, F. 2000. Effect of salt and smoke on the microbiological quality of cold-smoked salmon during storage at $5^{\circ} \mathrm{C}$ as estimated by factorial design method. J. Food Protect. 63: 502-508.

Leisner, J. J., Millan, J. C., Huss, H. H., and Larsen, L. M. 1994. Production of histamine and tyramine by lactic acid bacteria isolated from vacuum-packed sugar-salted fish. J. Appl. Bacteriol. 76: 417-423.

Niven, C. F., Jeffrey, M. B., and Corlett, D. A. 1981. Differential plating medium for quantitative detection of histamine-producing bacteria. Appl. Environ. Microbiol. 41: 321-322.

Ozogul, F., and Ozogul, Y. 2006. Biogenic amines content and biogenic amine quality indices of sardines (Sardina pilchardus) stored in modified atmosphere packaging and vacuum packaging. Food Chem. 99: 574-578.

Shalaby, A. R. 1996. Significance of biogenic amines to food safety and human health. Food Res. Int. 29: 675-690.

Silva, M. V., Pinho, O., Ferreira I., Plestilová, L., and Gibbs, P. A. 2002. Production of histamine and tyramine by bacteria 
isolated from Portuguese vacuum-packed cold-smoked fish. Food Control 13: 457-461.

Ten Brink, B., Damink, C., Joosten, H. M. L., and Huis in't Veld, J. H. J. 1990. Occurrence and formation of biologically active amines in foods. Int. J. Food Microbiol. 11: 73-84.

Til, H. P., Falke, M. K., Prinsen, M. K., and Willems, M. I. 1997. Acute and subacute toxicity of tyramine, spermidine, spermine, putrescine and cadaverine in rats. Food Chem. Toxicol. 35: 337-348.

Todorov, S. D., LeBlanc, J. G., Franco, B. D. G. M., and Vaz-Velho, M. 2012. Bacteriocin-producing lactic acid bacteria for biopreservation: Example of application in raw and processed salmon. In Lactobacillus: Classification. Uses and health implications, ed. A. I. Perez Campos and A. L. Mena, 65-92. New York, NY: Nova Biomedical.

Vaz-Velho, M., Todorov, S., Ribeiro, J., and Gibbs, P. 2005. Growth control of Listeria innocua 2030c during processing and storage of cold-smoked salmon-trout by Carnobacterium divergens V41 culture and supernatant. Food Control 16: 541-549.

Vaz-Velho, M., Silva, M., Pessoa, J., and Gibbs, P. 2006. Inactivation by ozone of Listeria innocua on salmon-trout during cold-smoke processing. Food Control 8: 609-616.

Vermeulen, A., Devlieghere, F., De LoyHendrickx, A., and Uyttendaele, M. 2011. Critical evaluation of the EU-technical guidance on shelf-life studies for $L$. monocytogenes on RTE-foods: A case study for smoked salmon. Int. J. Food Microbiol. 145: 176-185.

Van Spreekens, K. J. A. 1974. The suitability of a modification of Long and Hammer's medium for the enumeration of more fastidious bacteria from fresh fisheries products. Archiv fuer Lebensmittlehygiene 25: 213-219

Zhai, H., Yang, X., Li, L., Xia, Guobin, Cen, J., Huang, H., and Hao, S. 2012. Biogenic amines in commercial fish and fish products sold in southern China. Food Control 25: 303-308. 